\title{
Investigation of Change in Reading and Writing Attitudes of Primary School Students ${ }^{1}$
}

\author{
Nida Eminoğlu \\ Ministry of National Education \\ nidaeminoglu@gmail.com
}

\author{
Prof.Dr. Birsen Bağçeci \\ Gaziantep University-Turkey \\ bagceci@gantep.edu.tr
}

\begin{abstract}
:
The aim of this study is to examine the effects of activities applied to students on reading and writing attitudes and to evaluate the activities made by the parents. Mixed method was used in this study, where qualitative and quantitative methods were used together. The qualitative dimension of the research is to evaluate the activities carried out for the students by the parents. For this purpose, a semistructured interview form was used. In the quantitative dimension of the study, a single group pre-test and post-test weak experimental design were used to examine the effects of the activities prepared to improve students' attitudes towards reading and writing. After the t-test (Paired Samples t-Test) of 29 students in the study group to determine whether there was a difference between pre-test and post-test results of reading and writing attitudes, the average of pre-test scores before the experimental study. There was a significant difference between the mean posttest scores after the experimental study. Test results show that experimental study has a significant effect on reading and writing attitude. Test results show that the experimental study has a significant effect on the reading and writing attitudes. Besides, interviews were made with student' parents and their opinions about the experimental study were obtained. Based on the views of parents, it can be said that the experimental study has achieved its goals and succeeded to a large extent.

Keywords: Primary school, Primary school students, Reading attitude, writing attitude
\end{abstract}

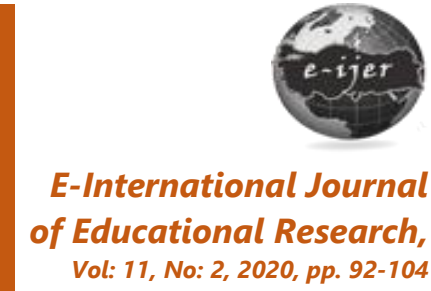

DOI: 10.19160/ijer.706766

Received: 2020-03-20 Accepted: 2020-06-15

\section{Suggested Citation:}

Eminoğlu, N. \&. Bağçeci, B. (2020). Investigation of Change in Reading and Writing Attitudes of Primary School Students, E-International Journal of Educational Research, Vol 11, No 2, 2020, pp. 92-104 DOI: 10.19160/ijer.706766

\footnotetext{
1 This research was produced from a master's thesis called "Investigation of Change in Reading and Writing Attitudes of Primary School Students".

Nida Eminoğlu, "Investigation of change in reading and writing attitudes of primary school students" Danışman: Doç. Dr. Birsen BAĞÇECi, Gaziantep Üniversitesi / Eğitim Bilimleri Enstitüsü / Eğitim Bilimleri Anabilim Dalı / Eğitim Programları ve Öğretim Bilim Dalı Sayfa:133s.Yıl:2019
} 


\section{INTRODUCTION}

The acquisition of reading and writing is basically a skill and habit gained in formal education. If students have not acquired these important skills during their school years, it will be very difficult for them to achieve in their adulthood. Reading and writing attitudes have a great effect on the habit of these skills. Smith (1990) defined reading attitude as a mental behavior triggered by emotions, which determines the time of reading, prolongs or decreases reading time (cited in Basaran, Ateş, 2009 p.77). A strong desire to write is as significant as the ability of the student to use their writing skills. Having a desire for writing also requires a positive attitude towards writing (Kırmızı, 2009). Positive attitudes toward reading and writing should be instilling in childhood. The most important elements of a favorable manner are teachers and parents.

In the literature, studies were conducted to investigate reading attitudes and behaviors of students (For example, Kurulgan and Çekerol, 2008; Arslan, Çelik and Çelik, 2009; Oğuz, Yıldız and Hayırsever, 2009). The common finding obtained as a result of these studies is that the reading attitudes and behaviors of students at every level are generally below the desired level among Turkish students. International exams also support this finding. It is possible to determine the striking results of the success of reading education in Turkey from international measurements. In 2016, in the Program for International Student Assessment (PISA), which is held by the Organization for Economic Cooperation and Development (OECD) and measured the success of countries with the participation of 18 million students, below 15 years old, from 64 counties, Turkey was ranked as the $50^{\text {th }}$ out of 72 countries while ranking lower in the reading section. In reading, Singapore, Hong Kong (China), Canada and Finland were ranked on the top. International exams reveal Turkey's shortcomings in reading. 35 countries, including Turkey, participated in PIRLS (2001) (Progress in International Reading Literacy Study). In the ranking of the scores, Turkey was ranked $28^{\text {th }}$ out of 35 countries.

It is observed that most of the studies on reading and writing attitudes in Turkey are studies that aim to describe the current situation. It was observed that there were studies that investigated the reading and writing attitudes of primary school students, studying between $1^{\text {st }}$ and $6^{\text {th }}$ grade (Yıldı and Kaman, 2016), studies that investigated the relationship between reading motivation and attitude, and reading comprehension in $5^{\text {th }}$ and $6^{\text {th }}$-grade students (Karahan, 2016), and studies that the relationship between the academic achievement of primary school students in Turkish course, and writing tendencies (Baş and Şahin, 2012). When the related literature was examined, it was observed that there were studies conducted internationally. In a study conducted by Wittrock (2003), it was aimed to improve the reading attitudes of $8^{\text {th }}$-grade students. At the conclusion of the study, it was found out that the students demonstrated a development of comprehension that was above the average by free reading in addition to improvements in reading activities and reading attitudes.

Edmunds and Bauserman (2006) conducted a study that aimed to determine the effects of teachers and education processes on reading attitudes while Curenton and Justice (2008) conducted a study to determine the reading skills of children whose families had low incomes. Evans and Shaw (2008) conducted a study to determine the effects of conducting reading activities with family on children's reading skills while Cottone (2013) conducted a study that aimed to reveal the relationship between mothers' education level and reading beliefs, and children's early literacy skills.

It was observed that scientific studies on improving reading and writing attitudes were insufficient although these are such important subjects in Turkey. Karadağ (2014) found that the theses conducted in our country are mostly limited to the studies that describe the current situation related to reading habits, interests, and attitudes; and he also obtained that there are no studies in the form of action, experimental and longitudinal studies. In the literature, it is seen that besides there are highly limited experimental studies to improve reading and writing attitudes and there is no experimental study involving the participation of educational stakeholders such as students, parents, and teachers. There is a need to carry out activities that will improve the 
reading and writing attitudes of the students in a positive way, in a planned way apart from the Turkish lesson, and include many elements such as the participation of the parents of the students. The niche in the relevant literature has been decisive in shaping the current research.

In this study, it was aimed to improve reading and writing attitudes of primary school second-grade students through activities based on teachers' opinions and the participation of parents of students in the process. Based on this idea, the problem sentence of the research is expressed as follows. How can reading and writing attitudes of second-year students in primary school be improved by activities based on the opinions of classroom teachers and the participation of parents of students in the process? In this study, pre-test and post-test results of second-grade students' attitudes towards reading and writing after 10 weeks of activity and parental views about the effect of activities on students will be tried to be determined and also what can be done to improve reading and writing attitudes will be determined. The aim of this study is to plan and implement activities to improve reading and writing attitudes of $2^{\text {nd }}$-grade students in addition to evaluating the effects of these activities on students' reading and writing attitudes via attitude surveys and parents' opinions. Within the framework of this aim, answers to the following questions were investigated.

1) Is there a significant difference between the reading attitude pretest and posttest results conducted before and after the experimental study?

2) Is there a significant difference between the writing attitude pretest and posttest results conducted before and after the experimental study?

3) What are the perceptions of parents towards the reading attitudes of the students included in the experimental group of the experimental study?

4) What are the perceptions of parents towards the writing attitudes of the students included in the experimental group of the experimental study?

\section{METHOD}

Mixed-method research design which includes qualitative and quantitative methods was used in the current study. The research was conducted on the basis of mixed method research, which was defined as the research in which the researcher collected and analyzed data, combined the findings, and concluded qualitative and quantitative research methods by Tashakkori and Creswell (2007). In this research, intertwined patterns, one of the mixed methods, were used. Quantified and qualitative data can be used sequentially or simultaneously in an embedded pattern called nested pattern by Creswell and Clark (2014).

In the study, the qualitative research method was adopted to evaluate the activities conducted for the students through the perceptions of the parents. While the qualitative research method provides detailed and in-depth data collection, it also enables to reveal the participants' individual perceptions, experiences and perspectives directly (Büyüköztürk, Çakmak, Akgün, Karadeniz ve Demirel, 2016). While the qualitative dimension of the research has constituted by the interviews which were made with classroom teachers; the quantitative part of the research was formed with the attitude scale which was used to measure the effectiveness of the 10 week activities conducted with the students.

Activities were implemented to improve students' reading and writing attitudes and these activities were also used to evaluate the effects of the pre-test and post-tests of the reading and writing attitude scales. The quantitative data gathered from pre-test and post-test results were supported by qualitative data obtained from the interviews of the parents of the students. This dimension of the research was constituted with case study design, one of the qualitative research designs. A case study is a research method based on how and why questions, which allows the researcher to investigate in depth a phenomenon or event that he or she cannot control (Yıldırım \& Şimşek, 2016). In the quantitative dimension of the study, a single group pre-test and post-test weak experimental design were used to examine the effect of the activities prepared on students 
'attitudes towards reading and writing to improve students' attitudes towards reading and writing. In this model, both pre-test and post-test measurements are made (Karasar, 2009). The reason for using this design in the study was the fact that the researcher was the form teacher of the classroom that constituted the experimental group. Therefore, the only group included in the study is the teacher's own classroom.

\section{Participants}

For the qualitative and quantitative aspects of the study, the participants, including students and parents, were explained under two subsections. The characteristics of the study group formed from the parents of the students for the qualitative aspect of the study were presented below.

When the education levels of the mothers of the students, who formed the experimental group with 29 students and subjected to the experimental study, it was discovered that $51.7 \%$ of the mothers were primary school graduates while $17.2 \%$ of them were literate in addition to $13.8 \%$ of the mothers who were secondary school graduates, $10.3 \%$ of the mothers who were illiterate and $7 \%$ of the mothers who were high school graduates. While $96.6 \%$ of the mothers of the students were housewives, $3.4 \%$ of them were working.

When the education levels of the fathers of the students included in the experimental group, it was determined that $48.3 \%$ of the fathers were primary school graduates while $17.2 \%$ of them were secondary school graduates in addition to $13.8 \%$ of the fathers who were high school graduates, $10.3 \%$ of the fathers who were university graduates, $7 \%$ of the fathers who were illiterate and $3.4 \%$ of the fathers who were literate. It was also revealed that $51.72 \%$ of the fathers of the students were workers while $17.24 \%$ of them were unemployed in addition to $17.24 \%$ of the fathers who were officers and $13.80 \%$ of the fathers who worked in other professions.

The experimental group, which was subjected to the experimental study, consisted of 17 female and 12 male students. By using Student Information Form, the number of books, except for the course books, in the houses of the students were determined. The numbers of the books in the houses of the students, which were included in the experimental group, were presented below.

Table 1. The number of books in the houses of the students included in the experimental group

\begin{tabular}{lll}
\hline Number of books in houses & Frequency $(\mathrm{f})$ & Percentage $(\%)$ \\
\hline Between 1-5 & 13 & 44.8 \\
Between 6-25 & 11 & 38 \\
Between 26-50 & 4 & 13.8 \\
51 and higher & 1 & 3.4 \\
\hline Total & 29 & 100 \\
\hline
\end{tabular}

When the numbers of books in the houses of the students who were included in the experimental group were examined, it was observed that $44.8 \%$ of them had between 1 and 5 books while $38 \%$ of them had between 6 and 25 books in addition to $13.5 \%$ of the students with between 26 and 50 books and $3.4 \%$ of the students with 51 books and higher.

The school where the experimental study was conducted is a state school that is located in the Perilkaya district of the Şahinbey county in the city of Gaziantep and the school is regarded as an obligatory service school.

\section{Data Collection Instruments}

The data collection tools used in this study are as the following:

- Prior to the experimental study, "Student Information Form" was conducted concurrently with the pretest in order to obtain information from the sample group, such as gender, parents' education level, socioeconomic level and the number of books in the house.

- Reading Attitude Survey: to determine the attitudes of the students towards reading, the Reading Attitude Survey $\left(1^{\text {st }}-6^{\text {th }}\right.$ grades), which was developed by McKenna and Kear (1990) and adapted into Turkish by Kocaaslan (2014) was employed. The Cronbach alpha coefficient of the reading attitude survey was calculated as 0.800 . This indicates that the 
survey has a highly reliable reliability coefficient and the reliability level of the survey in determining reading attitudes demonstrates that high accurate results can be obtained.

- Writing Attitude Scale: In this study, the Writing Attitude Scale ( $2^{\text {nd }}-6^{\text {th }}$ grades $)$, which was developed by Graham, Berninger and Fan (2007) was employed to determine the attitudes of the students towards writing. The items of the researchers, who developed the scale to measure attitudes towards writing, were adapted into Turkish by Göçer (2014). The Cronbach alpha coefficient of the writing attitude scale was calculated as 0.538 . When the measurement values were examined, it was observed that the scale had a rather low level of reliability coefficient. The reason for that could be the fact that the size of the sample of the study (29 students) was small.

- A semi-structured interview form was used as a data collection tool to be conducted with the parents in order to obtain the required data to evaluate the experimental study. The interview form consisted of two open-ended questions.

\section{Data Collection}

In the study, a semi-structured interview form was used as a data collection tool in order to evaluate the activities conducted for the students by the parents. In the preparation of the interview forms, conceptual information obtained from the literature revive on the subject, data collection tools in previous related studies and expert opinions were regarded as fundamentals. Opinions and perceptions of the interviewees were consulted without interfering with the expressions or thoughts of the interviewees. During the interviews, within the knowledge of the interviewees, sound recording and short note-taking on the interview form were practiced. In the study, the data obtained from the interviews conducted with the parents were analyzed by content analysis. Primarily, the data obtained from the interviews with parents were dictated. The codes that were collected under themes were assigned frequencies ( $f$ ) and percentages (\%). The codes that were similar to each other were gathered under the framework of certain concepts and themes, enabling the data to be understood easily. Analysis of the qualitative research data by content analysis was conducted with the steps of coding the data, finding the themes, arranging codes and themes, and identifying and interpreting the findings.

In the study, a normal distribution test was conducted to determine the statistical method to be used in the analysis of the data collected about reading and writing attitudes. The data regarding the reading and writing attitudes, which were obtained from the experimental group and which demonstrated normal distributions, were analyzed by parametric tests. In the SPSS statistical software, to investigate the effects of the activities conducted during the experimental study on the students' reading and writing attitudes, a $t$-test was conducted. The parametric test conducted to reveal whether there is a statistically significant difference between the means of the data obtained from two consecutive measurements on the same data source is called $t$-test (Paired Samples $t$-Test) for related (dependent) samples (Can, 2016 p.136). In addition to statistical significance, effect size (eta-squared value) was calculated.

\section{Validity and Reliability Precautions}

The interview form, which was developed by reviewing the literature and as a result of the content analysis of the answers given to the open-ended questions for the interviews conducted after the experimental study, was presented to two academics in the field of educational sciences as well as two teachers in order to obtain expert opinion for content validity. In line with the perceptions obtained from these individuals, the interview form was finalized after the necessary revisions. Themes (categories) were created by classifying the answers given to the open-ended questions. The themes were individually coded by two researchers, and they were presented to an experienced academic on the subject of qualitative research methods for re-coding. In this way, it was attempted to ensure the consistency (internal reliability) of the study. By making direct quotations, it was attempted to get to the bottom of the answers. In the literature, it is emphasized that the reliability of a study can be improved by consulting to expert opinion, answering by direct 
quotations, employing diversification and including more than one researcher (Yıldırım and Şimşek, 2016 p. 276). To improve the internal reliability of the study, the interviews conducted with the parents were recorded by using sound recording devices in addition to taking notes to collect the data without loss. To ensure the reliability of the study, the reliability formula of Miles and Huberman (2015) was used and the intercoder reliability was calculated as 0.80 .

\section{FINDINGS AND DISCUSSION}

In this section, the findings regarding the research problem were presented. The "Reading Attitude Survey and Writing Attitude Scale" were implemented as the pretest to collect the measurements regarding the dependent variable of the participants who were subjected to the experimental study, and the scores obtained from these scales were used as the pretest scores. Following the implementation of the experimental study, the "Reading Attitude Survey and Writing Attitude Scale" were implemented again and the results were evaluated as the posttest results. To discover the effects of the activities conducted during the experimental study on the students' reading attitudes, a $t$-test was conducted. The findings regarding the test results were presented in the table below.

Table 2. Findings related to the pretest-posttest results of the reading attitude survey

\begin{tabular}{lllllll}
\hline Measurement & $\mathrm{N}$ & $\overline{\mathrm{X}}$ & $\mathrm{S}$ & $\mathrm{Sd}$ & $\mathrm{T}$ & $\mathrm{P}$ \\
\hline Reading-pretest & 29 & 58.03 & 7.831 & 28 & -7.453 & .000 \\
Reading-posttest & 29 & 69.34 & 5.690 & & & \\
\hline
\end{tabular}

As a result of the paired samples $t$-test conducted to reveal whether there was a difference between the pretest and posttest reading attitudes of the 29 students -which were included in the experimental group of the experimental study- before and after the study, a significant difference was observed between the mean score of the pretest $(\bar{X}=58.03)$ conducted before the experimental study and the mean score of the posttest $(\bar{X}=69.34)$ conducted after the experimental study $\left[t_{28}=-7.453, p<0.001\right]$. The effect size calculated at the end of the test $(d=1.384)$ indicated that this difference was at a rather high level. Generally, in terms of the value of $d$, values higher than 1 are interpreted as rather high while 0.8 is considered high followed by 0.5 as medium and 0.2 as low (Can, 2016 p.141). This indicates that the activities conducted with the students in the experimental group had a significant effect on the reading attitude. The findings related to the effects of the experimental study on students' writing attitudes were presented in the table below.

Table 3. Findings related to the pretest-posttest results of the writing attitude scale

\begin{tabular}{lcccccc}
\hline Measurement & $\mathrm{N}$ & $\overline{\mathrm{X}}$ & $\mathrm{S}$ & $\mathrm{Sd}$ & $\mathrm{T}$ & $\mathrm{P}$ \\
\hline Reading-posttest & 29 & 14,03 & 2,872 & 28 & $-4,815$ &, 000 \\
Writing-posttest & 29 & 17,10 & 2,320 & & & \\
\hline
\end{tabular}

As a result of the paired samples $t$-test conducted to reveal whether there was a difference between the pretest and posttest writing attitudes of the 29 students -which were included in the experimental group of the experimental study-before and after the study, a significant difference was observed between the mean score of the pretest $(\bar{X}=14.03)$ conducted before the experimental study and the mean score of the posttest $(\bar{X}=17.10)$ conducted after the experimental study $\left[t_{28}=-4.815, p<0.001\right]$. The effect size calculated at the end of the test $(d=0.894)$ indicated that this difference was at a rather high level. This indicates that the activities conducted with the students in the experimental group had a significant effect on the writing attitude. The findings regarding the interview conducted after the experimental study with the parents of the students included in the experimental group were presented below. 
Table 4. Findings related to the reading attitudes of the students

\begin{tabular}{ccc}
\hline Improvement in Reading Attitude & $f$ & $\%$ \\
\hline Yes (I believe the reading attitude was improved.) & 23 & 79,31 \\
No (I believe the reading attitude was not improved) & 6 & 20,69 \\
\hline Total & 29 & 100 \\
\hline
\end{tabular}

Following the interview conducted with the parents of the students included in the experimental group of the experimental study, $79.31 \%$ of the parents stated that the reading attitudes of their children were improved while $20.69 \%$ of the parents stated that the reading attitudes of their children were not improved. The perceptions of the parents towards their children's improvement in reading attitudes were expressed as the following.

Participant P8:
"...Yes, I believe their reading attitudes were positively improved. My son reads his story for
three-four times to increase the circles in his reading worm".
Participant P27:
"...No, he did not use to like reading in the past. He does not like it now. I constantly have to warn him to read".

The findings regarding the interview conducted after the experimental study with the parents of the students included in the experimental group were presented below.

Table 5. Findings related to the writing attitudes of the students

\begin{tabular}{lcc}
\hline Improvement in Writing Attitude & $\mathbf{f}$ & $\mathbf{\%}$ \\
\hline Yes (I believe the writing attitude was improved.) & 24 & 82,76 \\
No (I believe the writing attitude was not improved) & 5 & 17,24 \\
\hline Total & 29 & 100 \\
\hline
\end{tabular}

Following the interview conducted with the parents of the students included in the experimental group of the experimental study, $82.76 \%$ of the parents stated that the writing attitudes of their children were improved while $17.24 \%$ of the parents stated that the writing attitudes of their children were not improved. The perceptions of the parents towards their children's improvement in writing attitudes were expressed as the following.

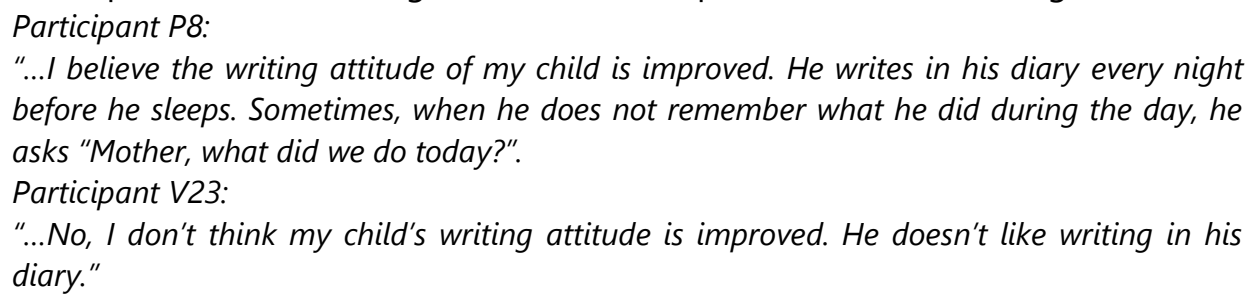

"...No, I don't think my child's writing attitude is improved. He doesn't like writing in his diary."

\section{DISCUSSION}

As a result of the paired samples $t$-test conducted to reveal whether there was a difference between the pretest and posttest reading attitudes of the 29 students -which were included in the experimental group of the experimental study- before and after the study, a significant difference was observed between the mean score of the pretest conducted before the experimental study and the mean score of the posttest conducted after the experimental study. The effect size calculated at the end of the test indicated that this difference was at a rather high level. Additionally, a similar result was obtained from the pretest-posttest results for the writing 
attitude. As a result of the paired samples $t$-test conducted to reveal whether there was a difference between the pretest and posttest writing attitudes of the 29 students -which were included in the experimental group of the experimental study- before and after the study, a significant difference was observed between the mean score of the pretest conducted before the experimental study and the mean score of the posttest conducted after the experimental study. The effect size calculated at the end of the test $(d=0.894)$ indicated that this difference was at a rather high level. This indicates that the activities conducted with the students in the experimental group had significant effects on reading and writing attitudes.

Similar to this study, Wittrock (2003) aimed to improve the reading attitudes of $8^{\text {th }}$-grade students through an 8-week study program. To discover the interest and attitudes of the students before and after the study, questionnaire forms and student interview forms were used. During the study, non-fictional texts and articles from the internet were used for students to read aloud. The students were also provided with novels, comic books, magazines, and non-fictional books. In conclusion, it was observed that the students demonstrated an improvement that was above the average by free reading and there were improvements in their reading attitudes and reading activities. As it can be seen in this study, maintaining reading and writing activities by planning them separately from lessons improves students' reading and writing attitudes. This study supports the current study. Within this scope, from a general perspective, it is possible to conclude from the findings of the study that a multifaceted education service can be conducted to improve reading and writing attitudes separately from the Turkish course and it can be effective.

After the experimental study was implemented, a parents' meeting was conducted to evaluate the students' reading and writing attitudes through the parents' perceptions. In the interview conducted after the implementation with the parents of the students included in the experimental group of the experimental study, $79.31 \%$ of the parents stated that the reading attitudes of their children were positively improved while $20.69 \%$ of the parents stated that the reading attitudes of their children were not positively improved. Contrary to this finding, in the study conducted by Öztürk and Aksoy (2016) that investigated the reading habits of primary school students by consulting to parents' perceptions, it was reported that $64.8 \%$ of the children had reading habits while $35.2 \%$ of them did not have reading habits. $74.1 \%$ of the parents stated that they cooperated with their teachers to get their children to adopt reading habits while only one-third of the parents (38.0\%) stated that they demonstrated behaviors that could be role models to their children in addition to a significant rate of the parents $(74.1 \%)$ stating the importance of reading and more than half of them (56.5\%) constantly warning their children to read.

In this study, based on the perceptions of the parents, it can be stated that the activities aimed to improve reading and writing attitudes achieved success. Considering the facts that the school where the experimental study was conducted was in an obligatory service region and the socioeconomic status of the parents were low, informing parents and the efforts to include them in the process played significant roles in the success of the experimental study that included activities aimed at improving reading and writing attitudes of students. Within this scope, in a general sense, based on the findings obtained from the conclusion of the study, it can be stated that an educational service aimed at improving reading and writing attitudes can be conducted and it can be effective.

\section{CONCLUSION AND RECOMMENDATIONS}

In the results of the $t$-test to determine whether there was a difference between the pre-test and post-test results of the reading attitudes of 29 students in the experimental group it was seen a significant difference $[\mathrm{t} 28=-4.815, \mathrm{p}<0.001]$ between the pretest scores $(\bar{X}=14,03)$ before the experimental study and the mean posttest $\operatorname{scores}(\bar{X}=17,10)$ after the experimental study. The effect size $(d=0,894)$ which was calculated at the end of the test shows that this difference is rather 
high. This situation shows that the activities applied to the students in the experimental group have a significant effect on reading and writing attitudes.

At the end of the interview with the parents of the students in the experimental group where the experimental study was applied it was seen that while $79.31 \%$ of the parents stated that their children's reading attitude improved positively; $20,69 \%$ stated that their children's reading attitude did not improve. Similar to this result, $82.76 \%$ of the parents stated that their children's writing attitude improved positively; $17.24 \%$ stated that their children's writing attitude did not change. In this context, it is possible to say that a multi-faceted teaching service aimed at improving reading and writing attitudes can be performed and can be effective from the findings obtained from the research in general. Based on the findings obtained as a result of the study, the following suggestions aimed at improving students' reading and writing attitudes were made.

Because the fundamentals of reading and writing attitudes are built in families, parents' awareness should be raised to get their children to adopt this habit. Teachers should be role models by primarily reading books and mentioning the books that they read. Open-air reading times can be formed and reading environments and their shapes can be made attractive. Extra time can be allocated to evaluate what students and teachers read. For this purpose, tools such as book suggestion form can be used.

Important duties fall to teachers and parents in children's development of positive reading and writing attitudes. Parents should take it as a duty to get their children to gain positive attitudes towards reading and listening by reading stories and tales to their children before they are at the school ages. Parents can be role models for their children by reading books at home and family reading times can be organized. On special occasions for the children (birthday, etc.) or important days, the values of books can be hinted by giving books as presents or enabling the children to give books as presents to their friends. By reviewing the time spent on devices such as televisions, telephones, tablets, and computers, a part of this time can be allocated for reading and writing activities with other family members. Children can be encouraged to buy books with a part of their pocket money received from their parents. In fact, sparing a part of their pocket money to buy books can enable children to build a "book fund".

It is observed that the thesis studies conducted in Turkey were generally limited to determining the present situation regarding the interest in reading, reading attitude and reading habit while there were few experimental studies or action research studies. Starting from the preschool period, programs can be developed for such a lesson aimed at reading and writing. This program, which would be developed for reading and writing for 5-6 year olds in the preschool period, and 1st, 2nd, 3rd and 4th grade primary school period, will help in improving reading and writing attitudes of children.

\section{REFERENCES}

Arslan, Y., Çelik, Z., ve Çelik, E. (2009). Üniversite öğrencilerinin okuma alışkanlığına yönelik tutumlarının belirlenmesi. PÜ Eğitim Fakültesi Dergisi, 26, 113-124.

Baş, G. ve Şahin, C. (2012). Illköğretim öğrencilerinin okuma tutumları, yazma eğilimleri ile Türkçe dersindeki akademik başarıları arasındaki ilişki. Turkish Studies, 7(3), 555 -572.

Başaran, M. ve Ateş, S. (2009). Illköğretim beşinci sınıf öğrencilerinin okumaya ilişkin tutumlarının incelenmesi. Gazi Üniversitesi Gazi Eğitim Fakültesi Dergisi, 29(1), 73-92.

Büyüköztürk, Ş., Çakmak, E. K., Akgün, Ö. E., Karadeniz, Ş., ve Demirel, F. (2016). Bilimsel araştırma yöntemleri. Ankara: Pegem Akademi.

Can, A. (2016). SPSS ile bilimsel araştırma sürecinde nicel veri analizi. Ankara: Pegem Akademi.

Cottone, E.A. (2013). Preschoolers' emergent literacy skills: The Mediating role of maternal reading beliefs. Early Education and Development, 23, 351-372.

Creswell, J. W., ve Clark, V. L. P. (2014). Karma yöntem araştırmaları: Tasarımı ve yürütülmesi (Y. Dede ve S. B. Demir, Çev.). Ankara: Anı Yayıncılık.

Curenton, S.M. ve Justice, L.M. (2008). Children's preliteracy skills: Influence of mothers' education and beliefs about shared-reading interactions. Early Education and Development, 19(2), 261-283. 
Edmunds, K. M. and Bauserman, K. L. (2006). What teachers can learn about reading motivation through conversation with children. The Reading Teacher, 59(5), 414-424.

Evans, M.A., Shaw, D. (2008). Home grown for reading: Parental contributions to young children's emergent literacy and word recognition. Canadian Psychology, 49(2), 89-95

Göçer,A. (2014). Yazma tutum ölçeğinin Türkçe'ye uyarlanması: Geçerlik ve Güvenirlik Çalışması, Kastamonu Eğitim Dergisi, 22(2),77-90.

Graham, S., Berningen, V. ve Fan, W. (2007). The structural relationship between writing attitude and writing achivement in first and third grade students, Contemporary Educational Psychollogy, 20-32.

Karadağ, R. (2014). Okuma ilgisi, tutumları ve alışkanlığı konusunda yapılmış çalışmaların lisansüstü tezlere dayalı analizi: YÖK ve Proquest veri tabanları örneklemi. Pamukkale Üniversitesi Eğitim Fakültesi Dergisi,(35)1,1-17.

Karahan, B. Ü. (2016). 5. Ve 6. sınıf öğrencilerinin okumaya karşı tutum ve motivasyonlarının okuduğunu anlama becerileri ile ilişkisi. Uluslararası Türkçe Edebiyat Kültür Eğitim (TEKE) Dergisi, 5(2),102-116.

Karasar, N. (2009). Bilimsel araştırma yöntemi. (19. Basım). Nobel: Ankara.

Kırmızı, F. S. (2009). Türkçe dersinde yaratıcı drama yöntemine dayalı yaratıcı yazma çalışmalarının yazmaya yönelik tutuma etkisi. Yaratıcı Drama Dergisi, 4(7), 51-68.

Kocaarslan, M. (2014). "Garfield" görselli 1-6. sınıflar için okumaya yönelik tutum ölçeğinin Türkçe uyarlama çalışması. Illköğretim Online, 15(4), 22-44.

Kurulgan, M. ve Çekerol, G. S. (2008). Öğrencilerin okuma ve kütüphane kullanmaları. Anadolu Üniversitesi Sosyal Bilimler Dergisi, 8(2),237-258.

Miles, M. B., \& Huberman, A. M. (2015). Nitel veri analizi. Çev. S. Akbababa Al-tun ve A. Ersoy). Ankara: Pegem Akademi.

Oğuz, E., Yıldız, A., \& Hayırsever, F. (2009). Assessing reading habits of future classroom teachers in the context of their socio-demographic features. International

Öztürk, D. S., Aksoy, E. (2016). İlköğretim öğrencilerinin okuma alışkanlığına ilişkin veli görüşleri. Abant lizzet Baysal Üniversitesi Eğitim Fakültesi Dergisi.16(2),110-123.

Progress in International Reading Literacy Study International Report.(2016).[Online] http://timssandpirls.bc.edu/pirls2006/intl_rpt.html adresinden 29.06.2017 tarihinde indirilmiştir.

Tashakkori, A., \& Creswell, J. W. (2007). The new era of mixed methods. Journal of Mixed Methods Research, $7(3), 3-7$.

Wittrock, J. J. (2003). Read all about it: finding ways to boost content comprehension and reading interest in an eighth grade science classroom. Pasific Lutheran University, Master of Arts in Education, 3(3),23-31.

Yıldırım, A., Şimşek, H. (2016). Sosyal bilimlerde nitel araştırma yöntemleri (10. baskı). Ankara: Seçkin Yayıncılık.

Yıldız, M. ve Kaman, Ş. (2016). İlköğretim (2-6. sınıf) öğrencilerinin okuma ve yazma tutumlarının incelenmesi. Türkiye Sosyal Araştırmalar Dergisi, 507-522. 


\section{ilkokul Öğrencilerinin Okuma ve Yazma Tutumlarındaki Değişimin incelenmesi $^{1}$}

\author{
Nida Eminoğlu \\ Milli Eğitim Bakanlığı \\ nidaeminoglu@gmail.com
}

\author{
Prof.Dr. Birsen Bağçeci \\ Gaziantep Üniversitesi-Türkiye \\ bagceci@gantep.edu.tr
}

\begin{abstract}
Özet:
Bu araştırmanın amacı ögrencilerin okuma va yazma tutumunu geliştirmeye yönelik uygulanan etkinliklerin, ögrrencilerin okuma ve yazma tutumlarına etkisinin incelenmesi ve öğrencilere yönelik yapılan etkinliklerin veliler tarafından değerlendirilmesidir. Nitel ve nicel yöntemlerin bir arada kullanıldığı bu çalışmada karma yöntem kullanılmıştır. Araştırmanın nitel boyutunu öğrencilere yönelik yapılan etkinliklerin veliler tarafından değerlendirilmesi oluşturmaktadır. Bu amaçla yarı yapılandırılmış görüşme formu kullanılmıştır. Araştırmanın nicel boyutunda ögrencilerin okuma ve yazmaya yönelik tutumlarını geliştirmek için hazırlanan etkinliklerin ögrencilerin okuma ve yazmaya yönelik tutumlarına etkisinin incelendiği tek grup ön test- son test zayıf deneysel desen kullanılmıştır. Deneysel çalışmanın uygulandığı denek grubunda bulunan 29 öğrencinin çalışma öncesi ve sonrası okuma ve yazma tutumu öntest-sontest sonuçları arasında bir fark olup olmadığını ortaya koymak için yapılan ilişkili örneklemler için $t$-testi (Paired Samples $t$-Test) sonucunda, deneysel çalışma öncesi yapılan öntest puan ortalaması ile deneysel çalışma sonrası yapılan sontest puanları ortalaması arasında anlamlı bir fark görülmüştür. Test sonuçları deneysel çalışmanın okuma ve yazma tutumu üzerinde anlamlı etkisinin olduğunu göstermektedir. Ayrıca öğrenci velileri ile görüşme yapılarak deneysel çalışma hakkında görüşleri alınmıştır. Veli görüşlerine dayanarak deneysel çalışmanın büyük ölçüde amaçlarına ulaştığı ve başarılı olduğu söylenebilir.
\end{abstract}

Keywords: Illkokul, ilkokul öğrencileri Okuma tutumu, Yazma tutumu

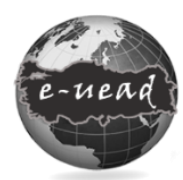

E-Uluslararası Eğitim Araştırmaları Dergisi, Cilt: 11, Sayı: 2, 2020, ss.92-104

DOI: 10.19160/ijer.706766

Gönderim: 2020-03-20 Kabul: 2020-06-15

\section{Önerilen Atıf:}

Eminoğlu, N. ve Bağçeci, B. (2020). İlkokul Öğrencilerinin Okuma ve Yazma Tutumlarındaki Değişimin İncelenmesi , EUluslararası Eğitim Araştırmaları Dergisi, Cilt: 11, Sayı: 2, 2020, ss. 92-104, DOI: 10.19160/ijer.706766

\footnotetext{
${ }^{1}$ Bu araştırma "illkokul Öğrencilerinin Okuma ve Yazma Tutumlarındaki Değişimin İncelenmesi" isimli yüksek lisans tezinden üretilmiştir. Tez Adı: Illkokul öğrencilerinin okuma ve yazma tutumlarındaki değişimin incelenmesi / Investigation of change in reading and writing attitudes of primary school students Danışman: Doç. Dr. Birsen BAĞÇECI, Gaziantep Üniversitesi / Eğitim Bilimleri Enstitüsü / Eğitim Bilimleri Anabilim Dalı / Eğitim Programları ve Öğretim Bilim Dalı Sayfa:133s.Yıl:2019
} 


\section{GENIŞLETILMIŞ ÖZET}

Problem: Bireyin okuma ve yazma edinmesi temelde örgün eğitimde kazanılan bir beceri ve alışkanlıktır. Öğrenciler okul yıllarında bu önemli becerileri edinmemişler ise, yetişkinlik dönemine geldiklerinde edinmeleri çok zor olur. Bu nedenle okuma ve yazmaya yönelik olumlu tutumların çocukluk yıllarında kazandırılması gerekir. Bunun en önemli öğeleri de öğretmen ve anne-babadır. Alanyazında okuma ve yazma tutumlarını geliştirmeye yönelik deneysel çalışmaların oldukça sınırlı olmasının yanında öğrenci, veli, öğretmen gibi eğitimle ilgili paydaşların bir arada katılımını içeren herhangi bir deneysel çalışma yapılmadığı görülmektedir. Bu araştırmanın amacı öğrencilerin okuma ve yazma tutumunu geliştirmeye yönelik uygulanan etkinliklerin, öğrencilerin okuma ve yazma tutumlarına etkisinin incelenmesi ve öğrencilere yönelik yapılan etkinliklerin veliler tarafından değerlendirilmesidir. Bu çalışma ikinci sınıf öğrencilerinin okuma ve yazma tutumlarını geliştirmeye yönelik etkinlikler planlayıp, uygulamak; bu etkinliklerin öğrencilerin okuma ve yazma tutumlarına etkisini tutum ölçekleri ve öğrenci veli görüşleri ile değerlendirmeyi amaçlamaktadır. Bu amaç çerçevesinde bu çalışmada aşağıdaki sorulara yanıt aranmıştır;

- Deneysel çalışma öncesi ve sonrası uygulanan okuma tutumu öntest-sontest sonuçları arasında anlamlı bir farklııı var mıdır?

- Deneysel çalışma öncesi ve sonrası uygulanan yazma tutumu öntest-sontest sonuçları arasında anlamlı bir farklıık var mıdır?

- Deneysel çalışmanın uygulandığı deney grubunda bulunan öğrencilerin okuma tutumlarına ilişkin veli görüşleri nelerdir?

- Deneysel çalışmanın uygulandığı deney grubunda bulunan öğrencilerin yazma tutumlarına ilişkin veli görüşleri nelerdir?

Yöntem: Nitel ve nicel yöntemlerin bir arada kullanıldığı bu çalışmada karma yöntem kullanılmıştır. Karma yöntem çeşitlerinden iç içe desen kullanılmıştır. Araştırmanın nitel boyutunu öğrencilere yönelik yapılan etkinliklerin veliler tarafından değerlendirilmesi oluşturmaktadır. Bu amaçla yarı yapılandırılmış görüşme formu kullanılmıştır. Araştırmanın bu boyutu nitel araştırma desenlerinden durum çalışması deseni ile desenlenmiştir. Araştırmanın nicel boyutunda öğrencilerin okuma ve yazmaya yönelik tutumlarını geliştirmek için hazırlanan etkinliklerin öğrencilerin okuma ve yazmaya yönelik tutumlarına etkisinin incelendiği tek grup ön test- son test zayıf deneysel desen kullanılmıştır. Öğrencilerin okumaya yönelik tutumlarını belirleyebilmek için orijinali McKenna ve Kear (1990) tarafından geliştirilmiş olan ve Kocaaslan (2014) tarafından Türkçe'ye uyarlanan Okuma Tutumu Ölçeği (1-6.sınıflar) kullanılmıştır. Öğrencilerin yazmaya yönelik tutumlarını belirleyebilmek için Graham, Berninger ve Fan (2007) tarafından geliştirilmiş olan (2-6.sınıflar için) Yazma Tutumu Ölçeği kullanılmıştır. Ölçeği geliştiren araştırmacılar yazma tutumunu ölçmeye yönelik maddeleri Göçer (2014) tarafından Türkçe'ye uyarlanmıştır.

Bulgular ve Tartışma: Deneysel çalışmanın uygulandığı denek grubunda bulunan 29 öğrencinin çalışma öncesi ve sonrası okuma tutumu öntest-sontest sonuçları arasında bir fark olup olmadığını ortaya koymak için yapılan ilişkili örneklemler için $t$ testi sonucunda, deneysel çalışma öncesi yapılan öntest puan ortalaması $(\bar{X}=58,03)$ ile deneysel çalışma sonrası yapılan sontest puanları ortalaması $(\bar{X}=69,34)$ arasında anlamlı bir fark görülmüştür [t28=-7.453, $p<0.001]$. Test sonucunda hesaplanan etki büyüklüğü $(d=1,384)$ bu farkın çok büyük düzeyde olduğunu göstermektedir. Bu durum, deney grubundaki öğrencilere uygulanan etkinliklerin, okuma tutumu üzerinde anlamlı bir etkisinin olduğunu göstermektedir. Deneysel çalışmanın uygulandığı denek grubunda bulunan öğrencilerin velileri ile uygulama sonrasında yapılan görüşmede öğrenci velilerinin \%79,31'i çocuklarının okuma tutumunun olumlu yönde geliştiğini belirtirken; \%20,69'u çocuklarının okuma tutumunun olumlu yönde gelişmediğini ifade etmişlerdir.

Sonuç ve Öneriler: Test sonuçları deneysel çalışmanın okuma ve yazma tutumu üzerinde anlamlı etkisinin olduğunu göstermektedir. Test sonucunda hesaplanan etki büyüklüğü bu farkın çok 
büyük düzeyde olduğunu göstermektedir. Bunun yanında yazma tutumu öntest-sontest sonuçlarında da benzer bir sonuç elde edilmiştir. Öğrenci velileri ile görüşme yapılarak deneysel çalışma hakkında görüşleri alınmıştır. Veli görüşlerine dayanarak deneysel çalışmanın öğrencilerin okuma ve yazma tutumlarını geliştirmede etkili olduğu söylenebilir. Bu bağlamda genel olarak araştırma sonucunda elde edilen bulgulardan okuma ve yazma tutumunu geliştirmeye yönelik Türkçe dersinden ayrı bir şekilde çok yönlü bir öğretim hizmetinin yapılabildiği ve etkili olabileceğini söylemek mümkündür. Illkokulda öğrencilerin okuma ve yazma tutumunu geliştirmeye yönelik bir program geliştirilmesi önerilmektedir. 